\title{
The hybrid trains in international logistics transportation
}

\author{
Zoia Kaira ${ }^{1}$, Liudmila Golovkova ${ }^{2, *}$, Ivan Rekun $^{2}$, and Yurii Trubai $^{2}$ \\ ${ }^{1}$ WSB University in Gdansk, Professor of management, 80-268 Gdansk, Grunwaldska 238A, Poland \\ ${ }^{2}$ DNURT, Department of Finance and economic security, 49010 Dnipro, Lazaryan Street 2, Ukraine
}

\begin{abstract}
Analytical information for the market players concerning to the overall future hybrid train market and the subsegments is considered. The forecast of the volume railway transportation in Ukraine is represented in the paper. The aim of the paper is to examine the role of hybrid trains in logistics transportation segment under escalating importance of international logistics where transport segment is influenced in largely degree of political, economic, social, technological, environmental and legal changes. The paper is targeted the stakeholders to provide with information on key market drivers, restraints, challenges, and opportunities.
\end{abstract}

\section{Background}

Transportation logistics issues are of great importance for business, as customers location and resourcing opportunities are widely disperced. Neglect of logistics aspects brings nor only higher costs but eventual noncompetitiveness, which will result in diminished market share, more expensive supplies or lower profits.logistics problems can prevent exporters from valuably benefiting potentially profitable market overseas.

The aim of the paper is to examine the role of hybrid trains in logistics transportation segment under escalating importance of international logistics where transport segment is influenced in largely degree of political, economic, social, technological, environmental and legal changes. The paper devoted getting information the market players on the overall hybrid train market and the subsegments. This will help stakeholders understand the competitive landscape and gain more insights to better position their businesses and plan suitable go-to-market strategies.

\section{Global trends in freight transport volumes}

The increasing demand for reducing carbon emissions and developing more efficient trains are expected to impact the growth of the hybrid trains market, and regulations regarding environmental issues to accelerate the gowth of hydrogen trains in close future.

The transport and logistics sector driven by market trends is undergoing an important transformation together with new technological solutions. National logistics performance is linked to a number of factors including legislation, international agreements, shipper performance and technology. Inadequate infrastructure and poor logistics services increase transport costs and delivery times whereas competitiveness becomes increasingly dependent on cost efficiency.

Along with remoteness, they are major determinants of a country's ability to participate in the world economy such as connectivity [1]. The importance of connectivity is very high in today's globalised economy, where value chains are increasingly interconnected and spread out all over the world [2]. Well-functioning logistics systems facilitate trade by lowering the cost of access to international markets and by improving the connectivity and competitiveness of domestic firms [3]. Connectivity can be defined as the centrality of a country to its relevant networks [2]. Connectivity reflects not only geography and the global structure of transport networks, but also trade transaction costs - which may increase economic distances and hence reduce connectivity [4]. Transport connectivity is fundamental to increasing country or region competitiveness. Better connectivity promotes regional integration, reduces trade costs and increases trade volumes, thereby promoting economic growth, social integration and development $[3,4,5]$.

Freight transport volumes are growing and this is dependent on state of economy. In the European Union the removal of internal borders and other market barriers contribute to the growth. Efficiency improvements have resulted in a reduction of real transport costs. This allows companies to benefit from differences in labour costs and skills in different regions. Transport over long distances is becoming more and more profitable compared to alternatives like local production [7]. Volume of freight transportation by type of carrier such as railway and motor vehicles in Ukraine is illustrated in the Table 1.

Transport system has a lot constraints in terms of transportation time, price, quality and social as well as ecological impact consequently it is important the question of weights, dimensions and modes of transport

* Corresponding author: g.liudmila22@gmail.com 
and IT support systems [7]. Taking into account globalisation impact, the growth of transport and the increasing environmental awareness of society, science and industry are seeking to identify solutions for sustainable freight transport. I $\mathrm{n}$ addition, policy makers in Europe are identifying a legislative framework to support a sustainable development for the anticipated growth of freight transport [6].

Table 1. Volume of freight transportation by type of carrier in Ukraine (thsd. tones) ${ }^{1}$

\begin{tabular}{|l|r|r|r|}
\hline \multirow{2}{*}{ Year } & \multicolumn{2}{|c|}{ Railway $^{\text {R }}$} & \multicolumn{1}{l}{$\begin{array}{l}\text { Motor } \\
\text { vehicles }\end{array}$} \\
\cline { 2 - 4 } & shipment & transportation & \\
\hline 1995 & 360225,3 & & 1816401,0 \\
\hline 1996 & 296050,7 & 342558,1 & 1254540,2 \\
\hline 1997 & 293523,5 & 341417,0 & 1249866,6 \\
\hline 1998 & 286321,5 & 335052,5 & 1081326,2 \\
\hline 1999 & 284244,3 & 334635,9 & 955329,1 \\
\hline 2000 & 295921,0 & 357381,6 & 938916,1 \\
\hline 2001 & 313089,0 & 370199,1 & 977268,8 \\
\hline 2002 & 330188,3 & 392592,0 & 947263,8 \\
\hline 2003 & 363364,7 & 445534,7 & 973283,0 \\
\hline 2004 & 388295,0 & 462367,6 & 1027396,3 \\
\hline 2005 & 378911,7 & 450277,3 & 1120715,3 \\
\hline 2006 & 398148,3 & 478711,4 & 1167199,7 \\
\hline 2007 & 415910,7 & 514192,9 & 1255225,3 \\
\hline 2008 & 399679,7 & 498536,8 & 1266598,1 \\
\hline 2009 & 322221,8 & 391523,4 & 1068857,9 \\
\hline 2010 & 357969,1 & 432897,0 & 1168218,8 \\
\hline 2011 & 388715,6 & 469308,1 & 1252390,3 \\
\hline 2012 & 378102,3 & 457454,5 & 1259697,7 \\
\hline 2013 & 377318,3 & 443601,5 & 1260767,5 \\
\hline 2014 & 325171,0 & 386276,5 & 1131312,7 \\
\hline 2015 & 294301,2 & 349994,8 & 1020604,0 \\
\hline 2016 & 292104,7 & 343433,5 & 1085663,4 \\
\hline 2017 & 277288,9 & 339550,5 & 1121673,6 \\
\hline 2018 & 267639,1 & 322342,1 & 1205530,8 \\
\hline
\end{tabular}

${ }^{1}$ According to the data of joint-stock company

"Ukrzaliznytsia".

In the Table 2 the method weighted moving average was used to forecast $\mathrm{D}$ - the volume of railway transportation in Ukraine. The forecast for period $t+1$ is a continuation of the average demand observed through period $t$. Thus we have

$$
\mathrm{F}_{\mathrm{t}+1}=\mathrm{A}_{\mathrm{t}}=\mathrm{W}_{1} \mathrm{D}_{\mathrm{t}}+\mathrm{W}_{2} \mathrm{D}_{\mathrm{t}-1}+\mathrm{W}_{3} \mathrm{D}_{\mathrm{t}-2},
$$

with the condition

$$
\sum_{i=1}^{3} W_{i}=1,
$$

where $\mathrm{W}_{1}=0,5 ; \mathrm{W}_{2}=0,3 ; \mathrm{W}_{3}=0,2$.

The forecast error is also shown as the difference between actual meaning $\mathrm{D}_{\mathrm{i}}$ and forecast $\mathrm{F}_{\mathrm{i}}$ in the Table 2 .

The forecast calculated for the volume of railway transportation in Ukraine illustrates Figure 1.ding to small growth.

Transport has several impacts on the environment. Emissions contribute to air pollution and climate change, noise causes nuisance and health risks and infrastructure has serious impacts on landscape and ecosystems. In addition to these impacts on the environment, transport has also other severe impacts on society [8]. The impacts of the transport sector as a whole are the sum of the impacts of the various transport modes. On the international freight transport market, rail transport is one of the most important modes, so it is needed to consider energy use of the transport sector.

Table 2. Moving-average forecasts of freight transportation in Ukraine, mln. $t$

\begin{tabular}{|l|l|r|r|r|}
\hline Year & $\mathrm{D}_{\mathrm{t}}$ & $\begin{array}{c}\mathrm{A}_{\mathrm{t}} \text { Three-Period } \\
\text { Moving Average })\end{array}$ & $\begin{array}{c}\mathrm{F}_{\mathrm{t}} \text { (Three- Period } \\
\text { Forecast })\end{array}$ & $\begin{array}{l}\text { Error } \\
\left(\mathrm{D}_{\mathrm{t}}-\mathrm{F}_{\mathrm{t}}\right)\end{array}$ \\
\hline 1996 & 342,6 & & & \\
\hline 1997 & 341,4 & & & \\
\hline 1998 & 335,0 & 340,7 & & \\
\hline 1999 & 334,6 & 338,1 & 340,7 & $-6,1$ \\
\hline 2000 & 357,4 & 339,4 & 338,1 & 19,3 \\
\hline 2001 & 370,2 & 348,6 & 339,4 & 30,8 \\
\hline 2002 & 392,6 & 368,3 & 348,6 & 4,4 \\
\hline 2003 & 445,5 & 340,0 & 368,3 & 77,2 \\
\hline 2004 & 462,4 & 422,4 & 340,0 & 70,4 \\
\hline 2005 & 450,3 & 451,5 & 422,4 & 27,9 \\
\hline 2006 & 478,7 & 462,0 & 451,5 & 27,1 \\
\hline 2007 & 514,2 & 471,6 & 462,0 & 52,2 \\
\hline 2008 & 498,5 & 493,3 & 471,6 & 26,9 \\
\hline 2009 & 391,5 & 485,0 & 493,3 & $-101,8$ \\
\hline 2010 & 432,9 & 453,3 & 485,0 & $-52,1$ \\
\hline 2011 & 469,3 & 419,6 & 453,3 & 16,2 \\
\hline 2012 & 457,4 & 448,8 & 419,6 & 37,8 \\
\hline 2013 & 443,6 & 460,7 & 448,8 & $-5,2$ \\
\hline 2014 & 386,3 & 439,1 & 460,7 & $-7,3$ \\
\hline 2015 & 350,0 & 407,7 & 439,1 & $-89,1$ \\
\hline 2016 & 343,4 & 366,8 & 407,7 & $-64,3$ \\
\hline 2017 & 340,4 & 346,0 & 366,8 & $-27,2$ \\
\hline 2018 & 322,3 & 338,0 & 346,0 & $-23,6$ \\
\hline 2019 & & & 338,0 & \\
\hline & & & & \\
\hline
\end{tabular}

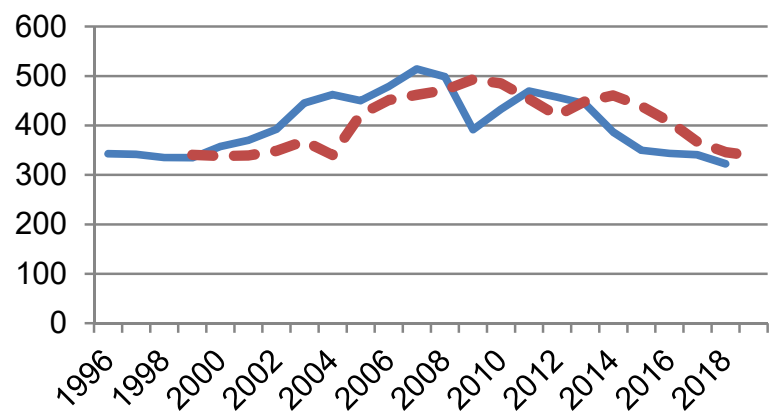

Fig.1. Forecast for the volume of freight transportation by railway carrier in Ukraine (1996-2018)

Source: authors' elaboration on the the data of joint-stock company "Ukrzaliznytsia".

\subsection{Energy use of the transport sector}

The trends in the energy use from transport over the last three decades of the previous century indicate the energy 
consumption of transport has almost doubled over this period [8]. The energy use of the transport sector is expected to grow much faster in the non-OECD countries than in the OECD countries. Where the nonOECD countries currently take about $36 \%$ of the worldwide transport related $\mathrm{CO}_{2}$ emissions, their share is expected to equal that of the OECD countries somewhere around 2040. The growth in the non-OECD countries has been even higher: the energy use almost tripled in these 30 years time. Both for OECD and nonOECD countries, road transport had by far the largest share: about three quarters, and this share is steadily increasing [8].

As elaborated in [8], international transport has generally a minor share in road transport $(8 \%$ in North America, 30\% in Europe). In rail transport, the share of international transport varies a lot $(5 \%$ in North America, 51\% in Europe). Worldwide the share of road and rail transport are currently roughly the same [9]. Also within the OECD, the share of road and rail is comparable (OECD, 2007). Azar made an assessment of the growth in freight transport worldwide between 1990 and $2100[9,10]$. The same study gives also estimates for the energy use in 2100 .

The results of this assessment are illustrated in Table 3.

Table 3. Growth in global freight transport volumes

\begin{tabular}{|l|c|c|c|c|}
\hline \multirow{2}{*}{} & \multicolumn{2}{|c|}{$\begin{array}{c}\text { Transport volume } \\
\text { in Ttkm/year }\end{array}$} & \multicolumn{2}{c|}{$\begin{array}{c}\text { Transport volume } \\
\text { in Ttkm/year }\end{array}$} \\
\cline { 2 - 5 } & 11990 & 22100 & 11990 & 22100 \\
\hline Road & 6,4 & 40 & 23 & 72 \\
\hline Rail & 6,1 & 13 & 3,1 & 4,3 \\
\hline Domestic water & 2,6 & 5 & 1,2 & 1,6 \\
\hline Ocean & 29 & 126 & 5,8 & 16 \\
\hline Air & 0,07 & 0,28 & 0,32 & 0,62 \\
\hline Total & 44 & 184 & 33 & 95 \\
\hline
\end{tabular}

Source: [9]

Table 3 reveals that despite of the growth in freight transport volume is expected to be strongest in road transport, the growth in rail transporty is estimated to be lower than the average. Despite of a probable improvement in fuel efficiency, the global energy use of freight transport is expected to triple [10].

This makes clear that the main driver behind the growing energy demand of freight transport is the transport growth [10]. Rail transport relies both on diesel and on electricity. The environmental performance of electric trains is generally better than that of diesel trains. The actual difference depends on electricity mix and the applied diesel technology. An important difference is that electric transport offers the possibility to use sustainably generated electricity. In that case the environmental performance of electric trains is much better than that of diesel trains. However, in an integrated electricity market, the marginal environmental impact from electric energy will be determined by the supplier of electricity. It is difficult to determine from which source any particular use of electricity stems [10].
Rail transport is responsible for $1.5 \%$ of the global transport energy use. Light duty vehicles (including passenger cars) have the highest share with $44 \%$. The other main energy users within the transport sector are aviation (12\%), maritime shipping (10\%) and buses $(6 \%)$. There are no worldwide statistics on the share of international road and rail freight transport in the energy use of total freight transport. However, data on the share of international freight transport in the transport volume can give a good indication.

The modal split differs a lot between countries. In Russia, the rail freight transport volume is several times larger than the road freight transport volume and also in China,the share of rail is much higher than that of road. In the USA, road and rail have rather comparable shares, while in Europe, rail transport has only a minor share in the inland freight market which is dominated by road transport [9]. As can be seen in Table 2, particularly the share of road transport is expected to increase strongly worldwide. The growth in road freight transport volumes is accompanied by a growth in both the number of vehicles and vehicle-kilometres. Figure 2 shows an estimate for the number of road freight vehicles worldwide [9].

Rail transport relies both on diesel and on electricity. The environmental performance of electric trains is generally better than that of diesel trains.

The actual difference depends on electricity mix and the applied diesel technology. An important difference is that electric transport offers the possibility to use sustainably generated electricity.

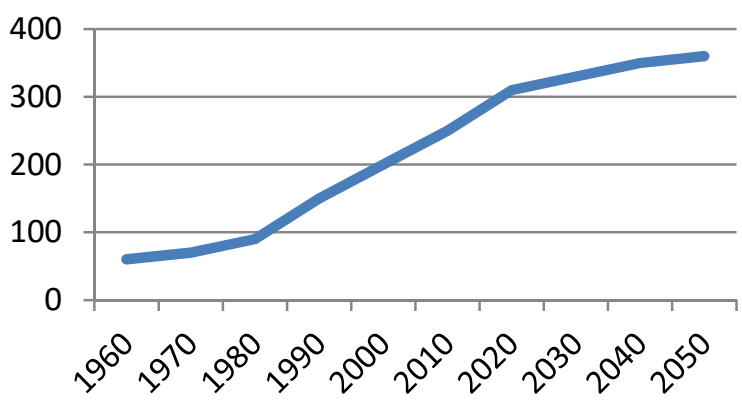

Fig. 2. Estimated trend of worldwide number of freight vehicles

Source:authors' elaboration on the base of [11]

In that case the environmental performance of electric trains is much better than that of diesel trains. However, in an integrated electricity market, the marginal environmental impact from electric energy will be determined by the "marginal" supplier of electricity. There is variation in logistical parameters, particularly load factors [9].

Differences exist in the energy mix of electricity used for electric trains. In specific markets, the differences between transport modes are generally small. Differences depend more on logistical characteristics and technology (e.g.emission standards) than on mode per se [8](Van Essen, et al., 2003). The current vehicle utilisation is a trade-off between the direct costs vehicle kilometres and the various cost of optimizing logistical 
chains. The second include costs related to time-losses, lower flexibility, storage, which might increase when vehicles are used in a more efficient way. Therefore, optimizing logistics is not just a task for the transport sector, but it is also related to governmental measures, in particular transport pricing [8].

\subsection{Opportunities to improve the environmental performance of freight transport}

Researches make clear the $\mathrm{CO}_{2}$ emissions of transport an increasing trend [8]. This is contrasting with the $\mathrm{CO}_{2}$ reduction targets discussed within the post-Kyoto climate policy and which have already been adopted by some countries (e.g. the European Union). In the short term, many developed countries will be able to meet their $\mathrm{CO}_{2}$ reduction goals under the Kyoto protocol without drastic measures in the transport sector. However, for the long term $\mathrm{CO}_{2}$ emission reductions of 40 to $60 \%$ compared to 1990 are expected to be necessary in order to limit the effects of global warming to acceptable levels [8]. Given the expected growth of the transport sector in the next decades and its strong reliance of fossil fuels, such long-term reduction goals cannot be met without significant contributions from the transport sector. Measures for $\mathrm{CO}_{2}$ reduction in international rail freight transport aimed at volume reduction and modal shift may contribute to a reduction of pollutant emissions, e.g. a shift towards electric rail transport in combination with a shift to greening electricity production [8].

Diesel electric locomotives may have most of what they need for regenerative braking since they might already use dynamic braking. This uses the traction motors as generators to absorb much of the train's energy, but without a way to store the generated electricity it is simply thrown into the atmosphere as heat with large rooftop resistor banks and cooling fans [8]. Using a storage system means that a non-fully electric train can use regenerative (as opposed to merely dynamic) braking, and even shut down the main power source whilst idling or stationary. Reducing energy consumption provides environmental benefits and economic savings [12]. The most important environmental impacts from the transport sector are caused by emissions of air pollutants, $\mathrm{CO} 2$ and noise. The contribution to air pollution is decreasing in most parts of the world, mainly due to various vehicle emission standards that have been implemented all over the world and are periodically tightened [9].

Only in those parts of the world that have an extremely high growth in transport volumes, the overall emissions of air pollutants may not yet ecrease. Noise is an important environmental problem which, just like air pollution, has severe health impacts causing high numbers of deaths each year. There are various measures that could be taken to reduce the contribution of freight traffic to ambient noise levels. The most cost-effective measures are those addressing the noise at-source. A mix of measures, like improving fuel efficiency of vehicles, alternative fuels and logistical improvements, is needed.
An effective policy for reducing the environmental impact of international rail transport should aim at improving the environmental performance of all modes of transport as well as ensuring a level playing field for the various modes. Regulation, infrastructure measures and pricing measures that take into account the environmental costs can contribute to this [9].

\section{Transport and Logistics Trends}

The transport and logistics sector is undergoing an important transformation as new technological solutions come into everyday use, driven by market trends [12]. This segment of the economy is influenced a large degree of political, economic, social, technological, environmental and legal changes. As complexity of modern transport and logistics grows, it is needed to realise what should be the short vs long term focus and what to invest in. An attempt to identify the key forces transforming the transport and logistics segment reveals that the hybrid train segment is expected to be the fastest growing market [12].

\subsection{Rail trains evolution}

It is worth to mention the idea of the railway started in about 600 BC during Greek and Roman times as ship dock ways, and the rails were simply grooves in limestone [13]. In the 16th century, railways appeared also in German and Austrian mines as they became the smartest way to transport large stone blocks. During the 18 th century, before the steam industrial revolution, the wagons were pulled by ponies very often named "Captain" as they were leading the convoy of stone and ore-filled carts. The idea of the railway started in about 600 BC during Greek and Roman times as ship dock ways, and the rails were simply grooves in limestone. In the early 1800 's, with steam gradually taking over as the means to supply large amounts of power, horses and ponies gave way to steam-powered locomotives. Some agreements were reached regarding railway gauges, and the first trains designed to carry goods and passengers started to appear [13].

In the $70 \mathrm{~s}$, the trend for non-electrically powered trains has been to reduce carbon dioxide emissions and to save energy [13]. The diesel-powered locomotives of today are already "hybrid" in a way that the diesel motor does not power the locomotive directly i.e. by means of a mechanical transmission. The high power delivery versus the load to be moved is so severe a contrast that it would rip apart most common mechanical transmission devices except for hydraulic converters. So, in order to deliver the power in a smooth manner, the diesel engine generates electricity on board the locomotive and powers a set of electric motors that gently transfer the power to the locomotive's wheels. Some of these engines also used a level of regenerative braking to save energy

The first truly hybrid locomotives appeared in the late 19th century and were equipped with lead-acid batteries. These were mainly used on tram lines or street railways. It is not known whether these early attempts 
really saved energy. Some smaller engines were equipped solely with lead-acid batteries to overhaul underground lines in London. The first near successful hybridization implementation attempt was initiated in the Czech Republic in 1986 but remained experimental [13].

In the 21 st century, Japanese hybrid machines made real progress in term of usability and advancement and started to make sense in terms of efficiency.

\subsection{Hybrid rail trains}

A hybrid train can be defined as a locomotive, railcar or train that uses an onboard rechargeable energy storage system (RESS), placed between the power source (often a diesel engine prime mover) and the traction transmission system connected to the wheels. Since most diesel locomotives are diesel-electric, they have all the components of a series hybrid transmission except the storage battery, making this a relatively simple prospect. Surplus energy from the power source, or energy derived from regenerative braking, charges the storage system. During acceleration, stored energy is directed to the transmission system, boosting that available from the main power source. In existing designs, the storage system can be electric traction batteries, or a flywheel. The energy source is diesel, liquefied petroleum gas, or hydrogen (for fuel cells) and transmission is direct mechanical, electric or hydrostatic [14]

Hydrogen train which works on hydrogen fuel cells is said to be a true eco-friendly train. Hydrogen train does not require a dual fuel system, which makes it a completely pollution-free and noise-free in operation achieving the need of an emission-free train. North America market is expected to register the fastest growth during the forecast period. The increasing demand for reducing carbon emission and developing more efficient trains are expected to propel the growth. BNSF with GE Transportation has planned to launch a diesel-electric locomotive by the end of 2020 [14].

The increasing concerns of carbon emission due to conventional railways and efficiency in this mode of transport have led the European authorities to develop a hybrid train network that has propelled the growth of this market. Government initiatives have encouraged the key players to develop the infrastructure for the train network. These trains have provided an opportunity for railway manufacturers to increase their presence in the region.

While diesel still plays a major part on many routes in many countries, rail is experimenting with new forms of power, including hydrogen fuel cells and batteries, while making old, dirty locomotives more efficient.

Today, the best hybrid trains are much more efficient. The batteries on board are able to store more and more energy and with the significant progress made in increasing the level of energy density in battery technology, the amount of energy stored on board is increasing. Through regenerative braking and on-board energy management to enable stop/start in stations. It has shown up to $10 \%$ fuel savings and $60 \%$ reduction in harmful emissions. However, batteries have a limited lifetime due to their limited number of cycles (c.3000) and they are still expensive to replace and difficult to recycle. The demand for the batteries is high during some of the charge-discharge cycles and this level of demand can damage them if it is not spread well enough across the battery pack. The bigger the pack, the higher the demand peak that can be dealt with. To some extent, any individual rolling stock could also move by itself and in that way ease the assembling of trains [13].

The transformation from diesel to hybrid-electric operation will allow a noise emissions reduction in stations by 75 percent, a 25 percent fuel consumption and $\mathrm{CO}_{2}$ emissions reduction. NOx emissions can also be reduced by up to 70 percent and particulate emissions by around 90 percent.The total operating costs of rail vehicles with MTU hybrid drives are also significantly lower, and even brake pads and discs experience reduced wear due to energy recuperation during braking. As a result of the additional power of the electric machine, train operators also have the option to improve journey times through better acceleration.

The importance of connectivity is very high in today's globalised economy, where value chains are increasingly interconnected and spread out all over the world. This is particularly important for catching-up economies trying to reduce their productivity gaps with the advanced countries, because higher-tech value chains tend to be particularly internationalised. It is needed to evaluate the up and coming Hybrid Train Market and how it will contribute to developing more sustainable transport solutions.

\subsection{Hybrid Train Market Trends}

Development of infrastructure and reduction in carbon emissions are significant factors for the growth of the hybrid train market globally [15].

Hydrogen trains don't require a dual fuel system, which makes it a completely pollution-free and noisefree in operation achieving the need of an emission-free train. The railway industry in North America is inclined towards innovation, technology, and development of high-performance and energy efficient trains. The increasing demand for reducing carbon emissions and developing more efficient trains are expected to propel the growth. The World Market for Hybrid Trains, 2019 to 2030: Estimated to Grow from 5,429 Units in 2019 to 9,109 Units by 2030 [15].

The global hybrid train market is estimated to grow from 5,429 Units in 2019 to reach 9,109 Units by 2030, at a CAGR of $4.8 \%$ (Figure 3 ).

Increased emphasis on reduction in carbon emissions is expected to boost the market [16]. Strict regulations regarding environmental issues are probably to accelerate growth of hydrogen trains during the forecast period. The hydrogen train segment is the fastest growing market. Hydrogen train which works on hydrogen fuel cells is said to be a true eco-friendly train. Hydrogen train does not require a dual fuel system, which makes it a completely pollution-free and noisefree in operation achieving the need of an emission-free 
train. Alstom with Eversholt Rail has introduced the first hydrogen fuel cell powered train in Germany in September 2018, which has already entered into the commercial services [15].

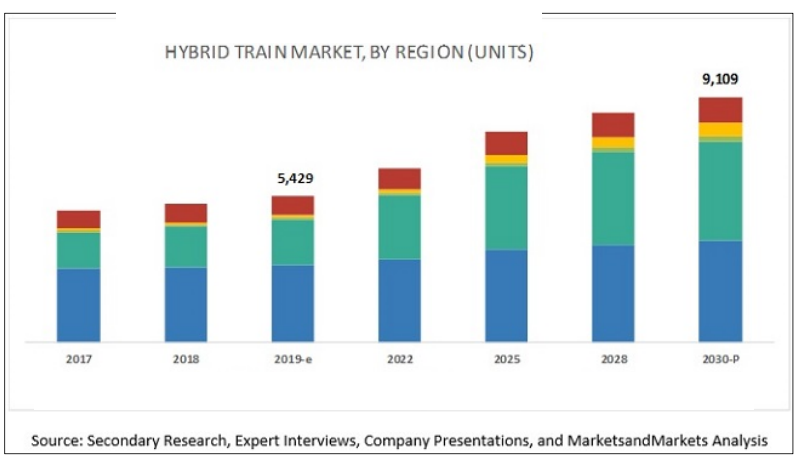

Fig. 3. Hybrid train market, by region (units) Source:[16]

The North America market is expected to witness the fastest growth, followed by the Middle East \& Africa. The US accounts for the largest share of the North American train market in 2018. The railway industry in the country is inclined towards innovation, technology, and development of high-performance and energyefficient trains. The increasing demand for reducing carbon emission and developing more efficient trains are expected to propel the growth. BNSF, Bombardier, and GE are some of the key players in the US railway industry. BNSF with GE Transportation has planned to launch a diesel-electric locomotive by the end of 2020 . The Asia Pacific is expected to be the largest market, followed by Europe. The increasing concerns of carbon emission due to conventional railways and efficiency in this mode of transport have led the European authorities to develop a hybrid train network that has propelled the growth of this market. Government initiatives have encouraged the key players to develop the infrastructure for the train network. These trains have provided an opportunity for railway manufacturers to increase their presence in the region [12].

While diesel still plays a major part on many routes in many countries, rail is experimenting with new forms of power, including hydrogen fuel cells and batteries, while making old, dirty locomotives more efficient [12].

\section{Conclusions}

The increasing concerns of carbon emission due to conventional railways and efficiency in this mode of transport have led the European authorities to develop a hybrid train network that has propelled the growth of this market. Government initiatives have encouraged the key players to develop the infrastructure for the train network. These trains have provided an opportunity for railway manufacturers to increase their presence in the region. While diesel still plays a major part on many routes in many countries, rail is experimenting with new forms of power, including hydrogen fuel cells and batteries, while making old, dirty locomotives more efficient.
Today, the best hybrid trains are much more efficient. The batteries on board are able to store more and more energy and with the significant progress made in increasing the level of energy density in battery technology, the amount of energy stored on board is increasing. A mix of measures, like improving fuel efficiency of vehicles, alternative fuels and logistical improvements, is needed. An effective policy for reducing the environmental impact of international rail transport should aim at improving the environmental performance of all modes of transport as well as ensuring a level playing field for the various modes. The up and coming Hybrid Train Market likely will contribute to developing more sustainable transport solutions.

\section{References}

1. OECD/ITF (2017), ITF Transport Outlook 2017, OECD Publishing, Paris. https://www.ttm.nl/wpcontent/uploads/2017/01/itf study.pdf

2. ITF (2019), "Enhancing Connectivity and Freight in Central Asia", International Transport Forum Policy Papers, No. 71, OECD Publishing, Paris.: https://www.itf-

oecd.org/sites/default/files/docs/connectivity-freightcentral-asia_2.pdf

3. J.-F. Arvis, , L. Ojala, B. Shepherd, D. Saslavsky, C. Busch, A. Raj (2014), Connecting to Compete 2014

4. The World Bank, 2014. Trade logistics in the global economy: the logistics performance index and its indicators; The World Bank, 2014.

5. ASEF (2016), ASEF Outlook Report 2016/2017, Asia-Europe Foundation, June 2016.

6. OECD (2018), Enhancing Connectivity through Transport Infrastructure: The Role of Official Development Finance and Private Investment, The Development Dimension, OECD Publishing, Paris, https://doi.org/10.1787/9789264304505-en

7. S. Jeschke. Global Trends in Transport Routes and Goods Transport: Influence on Future International Loading Units .https://www.acea.be/uploads/publications/SAG_16 Global_Trends_in_Transport_Routes_Goods_Trans port.pdf

8. H. van Essen. The Environmental Impacts of Increased International Road and Rail Freight Transport Past Trends and Future Perspectives 10-12 November 2008 in Guadalajara, Mexico. CE Delft, Delft, the Netherlands. http://www.oecd.org/greengrowth/greeningtransport/41380980.pdf

9. C. Azar, K. Lindgren and B. A. Andersson (2001). Hydrogen or methanol in the transportation sector? Goteburg, Goteburg University.

10. OECD. Globalisation, Transport and the Environment. OECD Publishing, 12 .01. 2010.- 276 p. 
11. Metz (2005), World Wide Emission Trend 1950 to 2050 Road Transport and all Sources, Eurochamp Workshop in Andechs, Chemistry, Transport and Impacts of Atmospheric Pollutants With Focus on Fine Particulates, October 2005, www.eurochamp.org/datapool/page/28/Metz.pdf

12. Powering the trains of tomorrow. 26 January 2017. https://www.railwaytechnology.com/features/featurepowering-the-trainsof-tomorrow-5723499/

13. Olivier Chabilan, Hybrid Locomotives, Ultracapacitors for the Railway Vehicles and Infrastructure. 2018

https://www.skeletontech.com/skeleton-blog/hybridlocomotives-ultracapacitors-for-the-railway-vehicles- and-infrastructure

14. Olivier Chabilan, Hybrid Locomotives, Ultracapacitors for the Railway Vehicles and Infrastructure Posted by Olivier Chabilan on - 07 February 2018

https://www.skeletontech.com/skeleton-blog/hybridlocomotives-ultracapacitors-for-the-railway-vehiclesand-infrastructure

15. UK, DVV Media. "GE unveils hybrid locomotive". Railway Gazette. Retrieved 2016-03-22.

16. Research and Markets. Dublin, May 07, 2019 (GLOBE NEWSWIRE) -- The "Hybrid Train Market by Propulsion, Operating Speed, Application, and Region - Global Forecast to 2030" 